\title{
PENGARUH MODEL PEMBELAJARAN ROLE PLAYING TERHADAP KETERAMPILAN BERBICARA SISWA KELAS IV SD PADA PEMBELAJARAN BAHASA INDONESIA
}

\author{
Asep Priatna1, Ghea Setyarini ${ }^{2}$ \\ 1,2STKIP Subang \\ 1aseppriatna064@gmail.com, 2setyarinig@gmail.com
}

\begin{abstract}
Based on the results of field studies conducted by researchers, the quality of teaching and speaking of students in grade IV SDN Sukamaju is still less active in terms of speaking, they prefer to talk during lessons, do not want to ask questions, say nothing and if the teacher asks to speak, students are still stammering, embarrassed and doubtful. With this in mind, it can be seen that fourth-grade students still do not have the speaking skills, and it is difficult to communicate the information obtained. Researchers are learning to role-play learning models for class IV student learning in Indonesian language learning and for class IV students' understanding by applying role-playing learning models to speaking learning in Indonesian language learning. The method used in this study is a quantitative study kind of quasi experiment conducted on students in class IV SDN Sukamaju with a total of 42 students, consisting of IV A 21 people and class IV B 21 people. This research uses the Nonequivalent Control Group Design. Data The results of the study were obtained from interviews, tests, questionnaires, observations, and documentation. The average value of the post-test class using conventional learning has an average value of 74.90. In contrast, the experimental class that uses the role-playing model has an average value of 80.19 . It can simplify learning by using role learning models that can help students in learning to read in learning Indonesian.
\end{abstract}

Keywords: Role Play Learning Model, Learning Skills

\begin{abstract}
ABSTRAK
Berdasarkan hasil studi lapangan yang dilakukan peneliti, keterampilan berbicara siswa kelas IV SDN Sukamaju masih kurang aktif dalam hal berbicara, kebanyakan mereka pasif saat pelajaran, tidak mau bertanya, diam saja dan jika guru meminta berbicara, siswa masih terbata-bata, malu dan ragu-ragu. Dengan memahami hal tersebut, dapat diketahui bahwa siswa kelas IV masih belum memiliki keterampilan berbicara dan sulit mengkomunikasikan informasi yang diperolehnya. Peneliti bertujuan ntuk mengetahui apakah pengaruh model pembelajaran role playing terhadap keterampilan berbicara siswa kelas IV pada pembelajaran Bahasa Indonesia dan untuk mengetahui sikap siswa kelas IV dengan menerapkan model pembelajaran role playing terhadap keterampilan berbicara pada pembelajaran Bahasa Indonesia. Metode yang digunakan dalam penelitian ini adalah penelitian kuantitatif jenis quasi experimen yang dilakukan pada siswa kelas IV SDN Sukamaju dengan jumlah 42 siswa, yang terdiri dari IV A 21 orang dan kelas IV B
\end{abstract}


21 orang. Penelitian ini menggunakan Nonequivalent Control Group Design. Data Hasil penelitian diperoleh dari wawancara, tes, angket, observasi dan dokumentasi. Nilai rata-rata pos-ttest kelas kontrol yang menggunakan pembelajaran konvensional memiliki nilai rata-rata sebesar 74,90, sedangkan untuk kelas eksperimen yang meggunakan model Role Playing memiliki nilai rata-rata 80,19. Dapat disimpulkan bahwa pembelajaran dengan menggunakan model pembelajaran role playing dapat sedikit membantu siswa dalam keterampilan membaca pada pembelajaran Bahasa Indonesia.

Kata Kunci: Model Pembelajaran Role Playing, Keterampilan Berbicara

\section{A. Pendahuluan}

Pendidikan merupakan suatu hal yang fundamental untuk pembangunan peradaban bangsa dan negara. Perkembangan dan perubahan peradaban pada perhelatan kehidupan di dunia saat ini memunculkan persaingan yang semakin kompetitif antar bangsa dalam berbagai lini kehidupan. Agar dapat mengambil peran dan diperhitungkan dalam persaingan tersebut, diperlukan sumber daya manusia yang mumpuni dan terampil dibidangnya sehingga dapat dikategorikan SDM yang berkualitas. Peningkatan kualitas SDM pada hakikatnya untuk membuat dan mengembangkan ilmu pengetahuan, dan teknologi, serta seni sebagai sarana untuk menjadi bangsa yang
mandiriPeningkatan sumber daya manusia dapat dilakukan melalui pendidikan. Menurut UU No. 20 tahun 2003 tentang Sisdiknas Bab I Pasal 1 (1) menyatakan: "Pendidikan merupakan usaha sadar dan terencana untuk mewujudkan suasana belajar dan proses pembelajaran agar siswa secara aktif mengembangkan potensi dirinya untuk memiliki kekuatan spiritual keagamaan, pengendalian diri, kepribadian, kecerdasan, akhlak mulia, serta keterampilaan yang diperlukan dirinya, masyarakat dan, negara".

Berbabagai upaya telah dikakukan pemerintah untuk meningkatkan kualitas pendidikan, diantaranya yaitu pembaharuan kurikulum, perbaikan sistem 
Pendas : Jurnal IImiah Pendidikan Dasar, ISSN Cetak : 2477-2143 ISSN Online : 2548-6950 Volume IV Nomor 2, Desember 2019

pembelajaran, peningkatan kualitas guru dalam bentuk Guru Pembelajar, dan berbagai hal lainnya. Salah satu upaya untuk meningkatkan kualitas pendidikan melalu proses pembelajaran diantaranya yaitu mencitptakan suasana belajar yang baik, mencipatakan pembelajaran berdasarkan pendekatan kebiasaan dan kesenangan mereka dalam belajar, sehingga mereka menjadi bersemangat dan senang dan mengikuti sepenuhnya dan seutuhnya proses pembelajaran yang sedang berlangsung.

Untuk mewujudkan hal tersebut sudah seyogyanya guru mencari informasi tentang kondisi-kondisi yang dapat meningkatkan kualitas pembelajaran di Sekolah Dasar. Bahasa Indonesia memiliki peran utama untuk mengembangkan ranah intelektual, sosial, dan emosional, dan keperibadian siswa dan merupakan factor utama penentu keberhasilan dalam mempelajari semua mata pelajaran yang ada di Sekolah Dasar. "Pembelajaran bahasa diharapkan membantu siswa mampu mengemukakan gagasan dan perasaan, berpartisipasi dalam masyarakat dan bahkan menemukan serta menggunakan kemampuan analitis dan imaginatif yang ada dalam dirinya" (Depdiknas, 2006:119).

Fokus utama pembelajaran Bahasa Indonesia terdiri dari empat aspek keterampilan berbahasa yaitu berbicara, menyimak, membaca, dan menulis. Berbicara sebagai suatu keterampilan berbahasa yang harus dimiliki setiap siswa setelah mereka memiliki keterampilan menyimak. Menurut Brown dan Yule (1983) (dalam Santosa, 2004:6.26) menyatakan bahwa "berbicara merupakan kemampuan mengucapkan bunyi-bunyi bahasa untuk mengekspresikan atau menyampaikan pikiran, gagasan, atau perasaan secara lisan".

Keempat aspek keterampilan berbahasa tersebut saling berkaitan satu sama lain, sehingga merupakan satu kesatuan utuh dan bersifat hierarkis, hal tersebut dapat diartikan bahwa keterampilan berbahasa yang satu akan menjadi dasar keterampilan 
Pendas : Jurnal IImiah Pendidikan Dasar, ISSN Cetak : 2477-2143 ISSN Online : 2548-6950

Volume IV Nomor 2, Desember 2019

berbahasa yang lain. Berbicara seringkali dianggap sebagai hal yang paling penting untuk kontrol sosial. Karena keterampilan berbicara merupakan salah satu bentuk perilaku manusia yang melibatkan faktor fisik, neurologis, linguistik, dan psikologis secara luas. Faktor-faktor tersebut dapat dijadikan penentu keberhasilan berbicara sehingga harus diperhatikan pada saat menentukan mampu tidaknya seseorang berbicara.

Berbicara sebagai suatu aktivitas yang dilakukan oleh siswa untuk mengadakan interaksi dengan orang lain. Namun demikian, di Sekolah Dasar yang penulis amati, sangat disayangkan bahwa keterampilan tersebut belum memperoleh perhatian yang serius dari guru. Guru masih sangat kurang untuk memfasilitasi siswa-siswanya dalam meningkatkan keterampilan berbicara pada kegiatan kegiatan pembelajaran bahasa Indonesia di kelas. "Keterampilan berbicara khususnya hanya dapat diperoleh dan dikuasai dengan jalan praktek dan banyak latihan" (Tarigan, 2015:1).
Berkaitan dengan dengan pernyataan di atas, pada kegiatan pembelajaran di Sekolah Dasar, berbicara merupakan salah satu bagian keterampilan berbahasa yang harus dikembangkan serta dikuasai secara utuh oleh siswa. Melalui keterampilan berbicara yang dikuasainya, siswa akan mampu berkomunikasi dengan baik dengan masyarakat di lingkungan mereka. Keterampilan berbicara yang dapat dikembangkan menjadi keterampilan berkomunikasi ini adalah satu keterampilan yang harus diberikan kepada setiap siswa. Namun demikian, berdasarkan hasil studi lapangan yang dilakukan peneliti di Sekolah Dasar, bahwa kualitas keterampilan berbicara siswa kelas IV SDN Sukamaju masih sangat kurang, diantaranya mereka kurang aktif dalam berbicara, mayoritas mereka masih pasif saat pelajaran berlangsung, siswa masih malu-malu dan sangat jarang ada bertanya, mereka hanya diam saja ketika guru meminta mereka untuk berbicara, siswa masih terbata-bata, malu dan 
Pendas : Jurnal IImiah Pendidikan Dasar, ISSN Cetak : 2477-2143 ISSN Online : 2548-6950

Volume IV Nomor 2, Desember 2019

ragu-ragu. Dengan memperhatikan beberapa hal tersebut, dapat disimpulkan bahwa mereka masih belum memiliki keterampilan berbicara dengan baik dan sulit untuk mengemukakan informasi yang telah diperolehnya.

Memperhatikan pentingnya siswa mempunyai keterampilan berbicara yang memadai dalam pembelajaran bahasa Indonesia maka diperlukan usaha dari guru dalam meningkatkan keduanya. Usaha yang dapat dilakukan oleh guru antara lain adalah menggunakan model pembelajaran role playing. "Role Playing dapat dikategorikan sebagai salah satu bagian dari strategi kooperatif learning karena peran selalu dimainkan dalam kelompokkelompok yang menuntut ketergantungan tinggi dari para anggotanya." (Prasetyo, 2001:72 dalam Isroni).

Selain itu, dengan adanya pengembangan keterampilan berbicara tersebut, mereka akan terbiasa untuk mengemukakan gagasan dan perasaan dengan baik, mampu berkomunikasi dengan efektif dan efisien, serta mampu mengembangkan kemampuan imajinatif dan analitis yang ada pada dirinya untuk menghadapi persoalanpersoalan yang muncul pada kehidupan sehari-hari.

Untuk mengatasi persoalan tersebut, penulis berkeyakinan solusi yang tepat yaitu dengan menggunakan model pembelajaran Role Playing. Hal tersebut didukong oleh pendapat Djamarah dan Zaini (2006:89) yang mengemukakan bahwa "salah satu keunggulan model role playing adalah bahasa lisan siswa yang dapat dibina menjadi bahasa yang baik agar mudah dipahami orang lain." Dengan demikian, melalui model pembelajaran role playing dirasa dapat menjadi cara yang tepat bagi siswa untuk belajar dan berlatih berbicara dan berkomunikasi dengan menilai aspek-aspek dalam berbicara, mengungkapkan perasaan melalui gerakan-gerakan serta ekspresi wajah (mimic), sehingga keterampilan berbicara dan berkomunikasi siswa semakin meningkat. 
Pendas : Jurnal IImiah Pendidikan Dasar, ISSN Cetak : 2477-2143 ISSN Online : 2548-6950 Volume IV Nomor 2, Desember 2019

Berdasarkan penelitian relevan yang dilakukan oleh Amalia (2013) yang berjudul "peningkatan keterampilan berbucara dengan teknik bermain peran pada siswa kelas III MI Ziyadatul Huda Jakarta Timur Tahun Pelajaran 2013/214" hasil penelitian menunjukan bahwa keterampilan siswa dalam berbicara mengalami peningkatan. "Saat pretest nilai ratarata siswa $60,5 \%$, siklus I 66,35\% dan siklus II 76,38\%. Ketuntasan klasikal saat pretest $29,41 \%$, siklus I $82,35 \%$ dan siklus II 100\%. Persentase peningkatan pada siklua I sebesar $38,41 \%$ dan pada siklus II sebesar 92,70\%. Keaktifan siswa mengalami kemajuan. Rata-rata jumlah skor yang diperoleh saat pretest sebesar 13 (berprestasi sedang), siklus I sebesar 22 (berprestasi tinggi) dan siklus II sebesar 30 (berprestasi tinggi). Dari hasil penelitian ini dapat disimpulkan bahwa teknik bermain peran dapat digunakan guru untuk meningkatkan keterampilan berbicara siswa".

Berdasarkan uraian yang dipaparkan di atas, maka penulis di dalam penelitian ini mengambil judul penelitian yaitu "Pengaruh Model Pembelajaran Role Playing Terhadap Keterampilan Berbicara Siswa Kelas IV pada Pembelajaran Bahasa Indonesia".

\section{B. Metode Penelitian}

Metode penelitian yang digunakan adalah metode kuantitatif. Alasan peneliti menggunakan metode penelitian ini dikarenakan peneliti ingin melihat sejauh mana pengaruh penerapan model pembelajaran Role Playing terhadap Keterampilan Berbicara siswa kelas IV. Desain penelitian yang digunakan yaitu Quasi Experimental Design hal tersebut dikarenakan peneliti tidak mengamati semua variabel yang mempengaruhi sampel yang diteliti, namun peneliti hanya melihat pengaruh dari variabel yang ditentukan saja.

Populasi dalam penelitian ini adalah seluruh siswa SDN Sukamaju Kecamatan Subang Kabupaten Subang pada tahun ajaran 20192020. Sampel penelitian ini yaitu siswa kelas IV di Sekolah Dasar Negeri Sukamaju dengan jumlah 42 
Pendas : Jurnal IImiah Pendidikan Dasar, ISSN Cetak : 2477-2143 ISSN Online : 2548-6950

Volume IV Nomor 2, Desember 2019

siswa, yang terdiri dari IV A 21 orang dan kelas IV B 21 orang.

C. Hasil Penelitian dan Pembahasan

1. Pengaruh Model Pembelajaran Role Playing terhadap Keterampilan Berbicara Siswa Kelas IV Pada Pembelajaran Bahasa Indonesia.

Berdasarkan hasil analisis skor dan pengolahan yang telah dilakukan diperoleh hasil bahwa model pembelajaran Role Playing berpengaruh terhadap keterampilan berbicara pada pembelajaran Bahasa Indonesia siswa kelas IV. Hal tersebut dilihat dari perbedaan nilai rata-rata antara kelas kontrol dan kelas eksperimen. Nilai rata-rata pos-ttest kelas kontrol yang menggunakan pembelajaran konvensional memiliki nilai rata-rata sebesar 74,90, sedangkan untuk kelas eksperimen yang meggunakan model Role Playing memiliki nilai rata-rata 80,19. Artinya siswa yang mendapatkan model pembelajaran Role Playing lebih baik daripada siswa yang mendapatkan

pembelajaran konvensional. Selain itu. berdasarkan pengujian hipotesis terhadap perbedaan hasil belajar kelas kontrol dan kelas eksperimen membuktikan bahwa pemberian perlakuan yang berbeda pada kedua kelas memberikan pengaruh terhadap perbedaan hasil belajar siswa pada kedua kelas tersebut. Dan penggunaan model pembelajaran role playing dalam kategori tinggi untuk meningkatkan hasil belajar keterampilan berbicara pada pembelajaran bahasa Indonesia.

Bagi siswa yang mendapatkan model Role Playing mereka akan terbantu melalui pengembangan imajinasi dan penghayatan siswa yang didalamnya terdapat aturan, tujuan, dan unsur senang dalam melakukan proses belajar mengajar (Santosa, 2004). Selain itu, mereka juga akan terlatih untuk mengemukakan gagasan dan perasaan secara cerdas dan kreatif, mampu berkomunikasi secara efektif dan efisien sesuai dengan etika yang berlaku, serta mampu menemukan 
Pendas : Jurnal IImiah Pendidikan Dasar, ISSN Cetak : 2477-2143 ISSN Online : 2548-6950 Volume IV Nomor 2, Desember 2019

dan menggunakan kemampuan analitis dan imajinatif yang ada dalam dirinya dalam menghadapi persoalan yang muncul dalam kehidupan seharihari.

Teori ini yang mendasari penggunaan model Role Playing dalam meningkatkan keterampilan berbicara pada pembelajaran Bahasa Indonesia. Guru akan membagikan scenario yang telah dipersiapakan, kemudia dibagikan kepada tiap kelompok dan memanggil para siswa yang sudah ditunjuk untuk melakonkan skenario yang sudah dipersiapkan. Model pembelajaran Role Playing bahasa lisan siswa yang dapat dibina menjadi bahasa yang baik yang mudah dipahami orang lain dan cara yang tepat bagi siswa untuk belajar dan berlatih berbicara dengan menilai aspek-aspek dalam berbicara mengungkapkan perasaan melalui gerakan-gerakan serta ekspresi wajah, sehingga keterampilan berbicara siswa semakin meningkat.

Dari hasil penelitian ini sejalan dengan penelitian terlebih dahulu yang telah dilakukan oleh Amalia
(2013) dengan judul "Peningkatan Keterampilan Berbicara Dengan Teknik Bermain Peran Pada Siswa Kelas III MI Ziyadatul Huda Jakarta Timur Tahun Pelajaran 2013/2014." Menyatakan bahwa kemampuan berbicara pada siswa kelas III MI Ziyadatul Huda terjadi peningkatan. "Peningkatan kemampuan berbicara tersebut dapat dibuktikan dengan meningkatnya nilai kemampuan menceritakan kembali isi dongeng yang diperankan pada setiap siklusnya, yaitu: sebelum tindakan nilai rata-rata kemampuan berbicara siswa 60,5 siklus I nilai rata-rata kemampuan berbicara siswa 66,35 dan sklus II nilai rata-rata kemampuan berbicara siswa $76,38 \%$. Tingkat ketuntasan belajar siswa pada kondisi awal sebanyak 5 siswa atau 29,41\% pada siklus I yaitu 14 siswa atau $82,35 \%$ dan siklus II sebanyak 17 siswa atau 100\%. Dengan demikian, penggunaan teknik bermain peran dalam pembelajaran menceritakan kembali isi dongeng dapat meningkatkan kemampuan berbicara 
Pendas : Jurnal IImiah Pendidikan Dasar, ISSN Cetak : 2477-2143 ISSN Online : 2548-6950 Volume IV Nomor 2, Desember 2019

pada siswa kelas III MI Ziyadatul Huda TP 2013/2014".

Dan yang dilakukan oleh Sari (2017) dengan judul "Peningkatan Keterampilan Berbicara Dengan Menggunakan Model Pembelajaran Kooperatif Think Pare Share Pada Mata Pelajaran Bahasa Indonesia Siswa Kelas V Di Min Lhoknga Aceh Besar." Dapat disimpulkan bahwa "kemampuan siswa dalam menceritakan teks bacaan hubungan makhluk hidup dengan ekosistem dengan penerapan model pembelajaran kooperatif think pair share dapat meningkatkan keterampilan berbicara siswa pada materi teks bacaan hubungan makhluk hidup dengan ekosistem atau ketuntasan peningkatan keterampilan berbicara siswa. Hal ini terlihat pada siklus I dari hasil persentase $(52,77 \%)$ hanya 19 orang siswa yang mencapai ketuntasan sedangkan disiklus II dari hasil persentase $(63,88 \%) 23$ orang siswa yang hanya mencapai ketuntasan individu sedangkan di siklus III jumlah siswa yang meningkat atau mencapai ketuntasan sebanyak
32 orang dengan persentase $88,88 \%$ baik secara individu maupun secara klasikal. Berdasarkan analisis tersebut siswa sudah mencapai KKM yang telah ditetapkan".

\section{Lembar Obervasi selama Proses}

\section{Pembelajaran}

Berdasarkan hasil penelitian observasi aktivitas siswa dengan menggunakan model pembelajaran role playing sudah baik. Hal ini dapat dibuktikan dengan hasil nilai persentase sebesar 76,43. Ini membuktikan bahwa penerapan dengan penerapan model pembelajaran role playing dapat meningkatkan aktivitas siswa dalam proses pembelajaran.

Hasil penelitian ini didukung oleh Nugraha (2013) yang mengemukakan bahwa "dengan menggunakan model role playing, dapat meningkatkan aktivitas dan hasil belajar. Selain itu, hasil penelitian observasi guru dalam penerapan model pembelajaran role playing sudah baik. Hal ini dapat dibuktikan dengan hasil nilai persentase sebesar $71,58 \%$ ". 
Pendas : Jurnal IImiah Pendidikan Dasar, ISSN Cetak : 2477-2143 ISSN Online : 2548-6950 Volume IV Nomor 2, Desember 2019

3. Sikap Siswa setelah melakukan

Pembelajaran Model Role

Playing Pada Pembelajaran

Bahasa Indonesia di Kelas IV.

Berdasarkan hasil kuisoner yang dilaksanakan setelah proses pembelajaran dilaksanakan, untuk kegiatan kognisi dalam kategori cukup baik dengan jumlah 280,95, untuk kegiatan konasi dalam kategori cukup baik dengan jumlah 338,10 dan untuk kegiatan afeksi dalam kategori cukup baik dengan jumlah 261,82. Dapat disimpulkan bahwa pembelajaran dengan menggunakan model pembelajaran role playing dapat membantu siswa dalam keterampilan membaca pada pembelajaran Bahasa Indonesia. Hasil penelitian ini didukung oleh Nugraha (2013) yang mengemukakan bahwa dengan menggunakan model role playing, dapat meningkatkan aktivitas dan hasil belajar.

Dari hasil penelitian ini sejalan dengan penelitian terlebih dahulu yang telah dilakukan oleh Novita (2016) dengan judul "Penerapan Model Pembelajaran Role Playing
Untuk Meningkatkan Motivasi dan Hasil Belajar Siswa Pada Mata PKn Kelas IV SD Negeri 2 Kesumadadi" dapat disimpulkan bahwa "penerapan model role playing dapat meningkatkan motivasi belajar siswa pada mata pelajaran PKn. Pada siklus I nilai rata-rata motivasi belajar siswa adalah 62,56, kemudian meningkat menjadi 76,08 pada siklus II". Dan hasil penelitian yang dilakukan oleh Silalahi (2018) yang berjudul "Upaya Meningkatkan Motivasi Belajar Siswa Dengan Menggunakan Metode Role Play Pada Pelajaran IPS Kelas IV SD Swasta Xavierus Padang Sidimpuan" dapat disimpulkan bahwa "dengan menggunakan metode role play telah memberikan ketertarikan serta keikutsertaan dan partisipasi siswa dalam kegiatan pembelajaran yang dilakukan. Dapat diketahui dari ratarata motivasi belajar siswa secara individu pada setiap siklus dan pertemuan pada pembelajaran IPS pokok bahasan masalah-masalah social mengalami peningkatan dari Siklus I Pertemuan I sebesar 57,23\%, Siklus I Pertemuan II sebesar $74,76 \%$, 
Pendas : Jurnal IImiah Pendidikan Dasar, ISSN Cetak : 2477-2143 ISSN Online : 2548-6950

Volume IV Nomor 2, Desember 2019

Siklus II Pertemuan I sebesar 80,83\%,

Siklus II Pertemuan II sebesar

$86,76 \%$. Pada observasi guru Siklus I

Pertemuan I sebesar 72,05\% (baik),

Siklus II Pertemuan I sebesar 76,47\%

(baik), Siklus II Pertemuan II sebesar

$89,70 \%$ (sangat baik)".

\section{Kesimpulan}

Berdasarkan hasil penelitian dan analisis data tentang "Pengaruh Model Pembelajaran Model Pembelajaran Role Playing terhadap Keterampilan Berbicara Siswa Kelas IV SDN Sukamaju, diperoleh kesimpulan sebagai berikut:

1. Penerapan Model Pembelajaran Role Playing terhadap Keterampilan Berbicara Siswa Kelas IV SDN Sukamaju, adanya pengaruh yang signifikan dan dapat dibuktikan dengan adanya perbedaan hasil belajar setelah pembelajaran antara kelas eksperimen dengan kelas kontrol. Nilai rata-rata post-test kelas eksperimen lebih baik dengan nilai post-test 80,19 dibandingkan dengan kelas kontrol yang menggunakan

pembelajaran konvensional dengan rata-rata nilai post-test 74,90 . Selain itu, penggunaan model pembelajaran role playing dalam ketegori sedang dengan skor 0,51 untuk meningkatkan hasil belajar terhadap keterampilan berbicara siswa pada pembelajaran bahasa Indonesia.

2. Sikap belajar siswa setelah pembelajaran dalam kegiatan kognisi dalam kategori cukup baik dengan jumlah 280,95, kegiatan konasi dalam kategori cukup baik dengan jumlah 338,10 , dan untuk kegiatan afeksi dalam kategori cukup baik dengan jumlah 261,82 . Dapat disimpulkan bahwa pembelajaran dengan menggunakan model pembelajaran role playing dapat membantu siswa dalam keterampilan berbicara pada pembelajaran bahasa Indonesia. 
Pendas : Jurnal IImiah Pendidikan Dasar, ISSN Cetak : 2477-2143 ISSN Online : 2548-6950

Volume IV Nomor 2, Desember 2019

\section{DAFTAR PUSTAKA}

Amalia, Lilik. (2013). Peningkatan Keterampilan Berbicara dengan Teknik Bermain Peran pada Siswa Kelas III MI Ziyadatul Huda Jakarta Timur Tahun Pelajaran 2013/2014. Skripsi. PGMI-UINSH.

Djamarah, S, B. dan Aswan, Z. (2006). Strategi Belajar Mengajar. Jakarta: Rineka Cipta

Sari, Linda. (2017). Peningkatan Keterampilan Berbicara Dengan Menggunakan Model Pembelajaran Kooperatif Think Pair and Share Pada Mata Pelajaran Bahasa Indonesia Siswa Kelas V Di Min Lhoknga Aceh Besar. Skripsi. PGMIUINAR-RANIRY.

Tarigan, H.G. (2015). Berbicara Sebagai Salah Suatu Keterampilan Berbahasa. Bandung: Angkasa Bandung.

Depdikbud. (2003). Undang-undang Republik Indonesia No. 20 Tahun 2003 Tentang Sistem Pendidikan Nasional Bab I Pasal I. Jakarta : Depdikbud
Puji, Santosa. (2004). Materi dan Pembelajaran Bahasa Indonesia SD. Jakarta: Universitas Terbuka Isroni, Isroni (2014) Penerapan Metode Role Playing Untuk Meningkatkan Keterampilan Berbicara Pada Mata Pelajaran Bahasa Indonesia Siswa Kelas VI SD Negeri 3 Putatnganten Tahun Pelajaran 2013/2014. Skripsi. Universitas Muhammadiyah Surakarta.

Nugraha, Nareswara. (2013). Penerapan Model Role Playing untuk meningkatkan Aktivitas dan Hasil Belajar IPS siswa Kelas V SDN Kedundung 1 Kota Mojokerto. Skripsi, S1 Pendidikan Guru Sekolah Dasar Jurusan Kependidikan Sekolah Dasar dan Prasekolah, Fakultas IImu Pendidikan, Universitas Negeri Malang.

Novita, Dewi.(2016). Penerapan Model Pembelajaran Role Playing untuk Meningkatkan Motivasi dan Hasil Belajar Siswa pada Mata Pelajaran PKn Kelas IV SD Negeri 2 Kesumadadi. Skripsi. Universitas Lampung. Tidak Diterbitkan 


Silalahi, Wesly. (2018). Upaya
Meningkatkan Motivasi Belajar
Siswa dengan Menggunakan
Metode Role Playing Pada
Pelajaran IPS Kelas IV SD
Swasta Xaverius Padang
Sidimpuan. School Education
Journal (SEC). Vol. 8 No. 2 Juni
2018.

